\title{
₹USGS
}

science for a changing world

\section{Spatial Digital Database for the Geology of the San Pedro River Basin in Cochise, Gila, Graham, Pima, and Pinal Counties, Arizona}

By Karen S. Bolm ${ }^{1}$, Tasha Lewis ${ }^{2}$, Douglas M. Hirschberg ${ }^{2}$, G. Stephen Pitts ${ }^{2}$, and William R. Dickinson ${ }^{3}$

Open-File Report 02-393

Digital database, version 1.0

2002

Database approved for publication September 30, 2002

This report is preliminary and has not been reviewed for conformity with U.S. Geological Survey editorial standards or with the North American Stratigraphic Code. Any use of trade, product, or firm names is for descriptive purposes only and does not imply endorsement by the U.S. Government. The digital database is not meant to be used or displayed at any scale larger than 1:24,000 (for example, 1:12,000).

\section{U.S. DEPARTMENT OF THE INTERIOR U.S. GEOLOGICAL SURVEY}

${ }^{1}$ U.S. Geological Survey, 520 N. Park Ave. \#355, Tucson, Arizona 85719

${ }^{2}$ University of Arizona, 520 N. Park Ave., Tucson, Arizona 85719

${ }^{3}$ Emeritus, University of Arizona, 4831 Via Sonrisa, Tucson, Arizona 85718 


\section{Table of Contents}

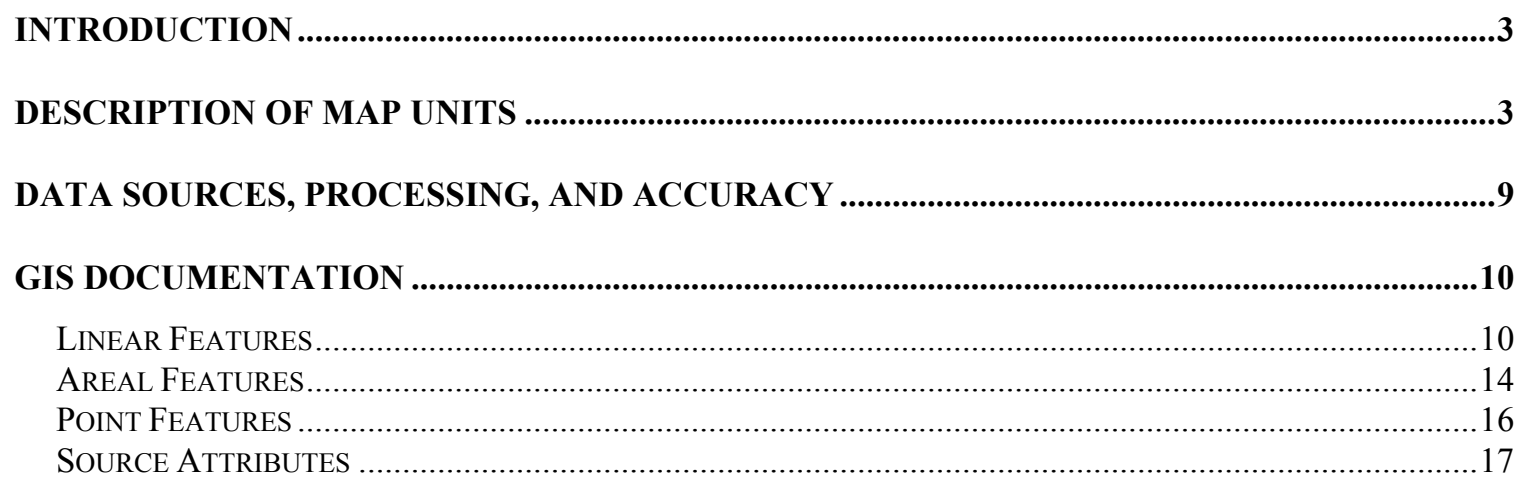

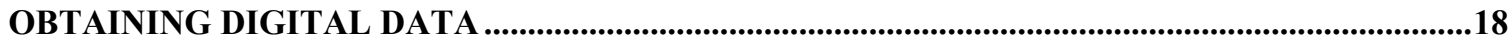

OBTAINING PAPER MAPS ..................................................................................................................18

REFERENCES CITED .........................................................................................................................................19

APPENDIX A - LIST OF FILES IN THE QUIBURIS GIS ............................................................20

APPENDIX B - METADATA FILE (QUIB24K.MET) FOR THE QUIBURIS GIS.............................22

\section{List of Figures}

Figure 1. Index map showing the geographic extent of the spatial digital database (black fill) with respect to Arizona counties

Figure 2. Explanation for the simplified geologic map of the San Pedro River Basin, Arizona.

Figure 3. Simplified geologic map the San Pedro River Basin, Arizona.

Figure 4: Relationships between feature attribute tables and look-up tables. 11 


\section{Introduction}

This spatial digital database for the geology of the San Pedro River Basin in southeastern Arizona was compiled from three maps by Dickinson (1993, 1998, 2000). Mylar originals of the map sheets were scanned, and the resultant images were rectified to a mathematically-generated set of latitude and longitude registration points. Geologic linework was digitized from the rectified images on screen using ArcView (ver. 3.2), and the resultant shapefiles were converted to ArcInfo (ver. 7.2) coverages. Lines and polygons were then attributed; and the files were merged omtp a single ArcInfo database (quib24k).

This digital spatial database is one of many being created by the U.S. Geological Survey as an ongoing effort to provide geologic information in a geographic information system (GIS) for use in spatial analysis. This database can be queried in many ways to produce a variety of geologic maps. Digital base map data files (topography, roads, towns, rivers and lakes, etc.) are not included: they may be obtained from a variety of commercial and government sources. This database is not meant to be used or displayed at any scale larger than 1:24,000 (for example, 1:12,000).

The map area is located in southeastern Arizona (fig. 1). This report describes the map units, the methods used to convert the geologic map data into a digital format, and the ArcInfo GIS file structures and relationships; and it explains how to download the digital files from the U.S. Geological Survey public access World Wide Web site on the Internet. See figures 2 and 3 for page-size versions of the map compilation.

Manuscript and digital data review by Helen Kayser is greatly appreciated.

\section{Description of Map Units}

Unit descriptions were adapted from Dickinson (1998), Dickinson (1993), and Dickinson (2000).

Qfa Floodplain alluvium of Gila and San Pedro river valleys, the modern axial streams of the San Pedro trough, and Aravaipa Creek (Holocene)

Qaf Alluvium (Holocene)-Tributary alluvial fans

Qtg Stream terrace gravels of San Pedro River (Quaternary)

Teg Gravels of Camp Grant (Pliocene) — Unconsolidated to semi-consolidated gravels and locally sandy deposits, partial equivalent of Quiburis Formation 


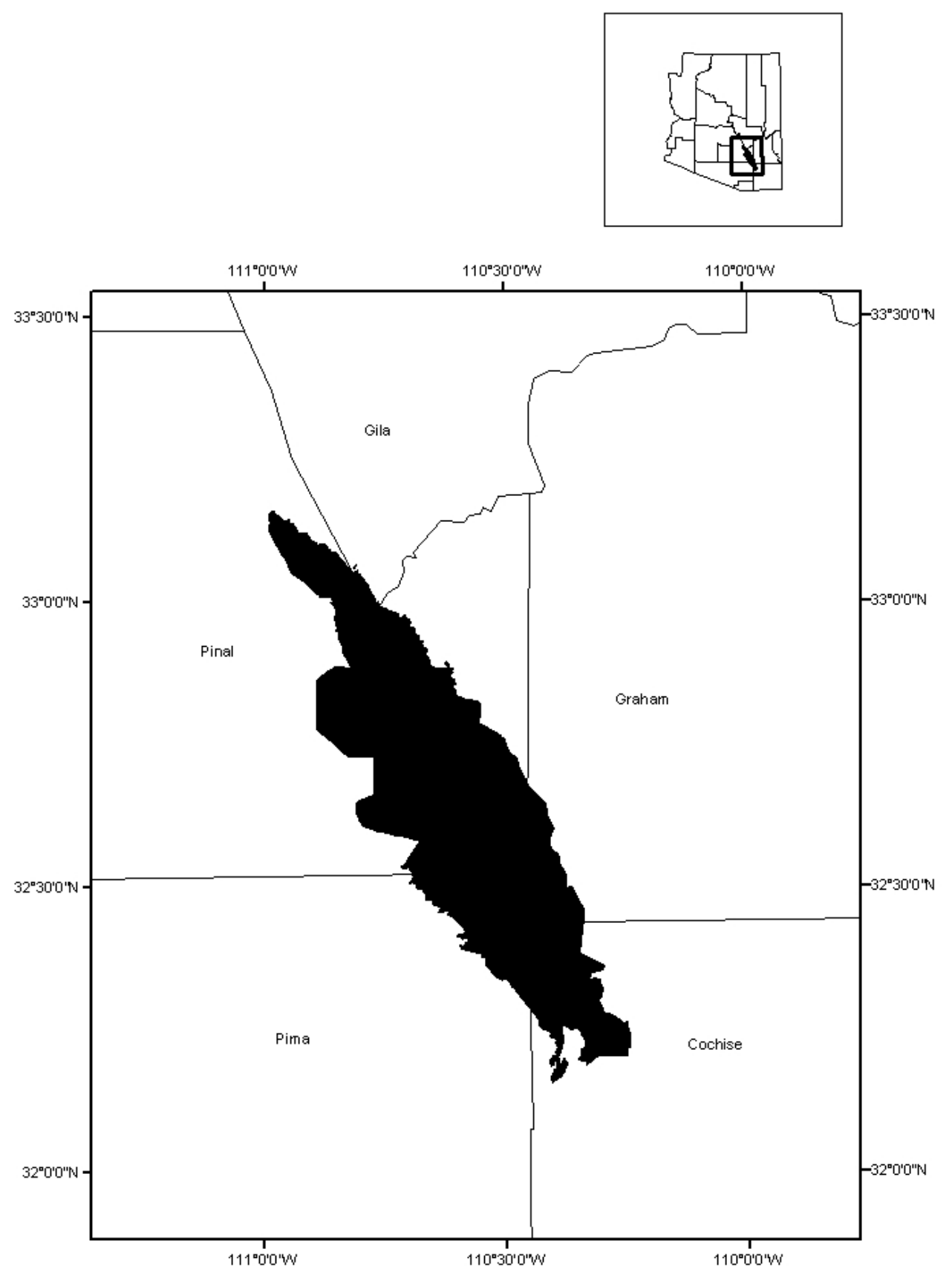

Figure 1. Index map showing the geographic extent of the spatial digital database (black fill) with respect to Arizona counties 


\section{List of Map Units}

Qfa - floodplain alluvium (Holocene)

Qaf - alluvium (Holocene)tributary alluvial fans

$\square$ Qtg - San Pedro River stream terrace gravels (Quaternary)

$\square$ Tcg - gravels of Camp Grant(Pliocene)

$\square$ Tq - Quiburis Formation (Miocene-Pliocene?)

$\square$ Tqc - Gravelly alluvial-fan and braidplain facies

$\square$ Tqcr - rubbly bajada facies of the gravelly alluvial-fan and braidfacies (Tqc)

$\square$ Tqs - sandy fan-toe, lake margin, and delta-front sandflat facies

Tqse - Prominent delta-front subfacies of Eskiminzin Delta

$\square$ Tqsr - Extensive alluvial plain subfacies (Redington Member) of sandstone beds

$\square$ Tqsrg - Area of 1-10 cm gypsum stringers in sandstone in Tqsr
Tqm - Massive prodelta mudstone

Tql - Laminated lacustrine facies

Tqld - Diatomaceous facies of Tql

Tsm - San Manuel Formation (Lower Miocene)

Tssz - Soza Canyon facies

Tspg - Paige Canyon facies

Tske - Kelsey Canyon facies

Tbw - Beehive Well member

Tsmb - Debris-avalanche megabreccia

$\square$ Tst - Tucson Wash Member

$\square$ Tsk - Kanally Member

$\square$ Tvy - Olivine-bearing basaltic andesite lava (Miocene)

Trf - Rhyodacite to rhyolitic felsite domes and plugs (Upper Oligocene to Lower Miocene)
Cloudburst Formation (Oligocene-Miocene)

$\square$ Tcs - Sedimentary upper member

$\square$ Tch - Hackberry Wash facies

$\square$ Tcv - Volcanic lower member

$\square$ Tgv - Galiuro Volcanics (Oligocene-Miocene)

$\square$ Tmi - Mineta Formation (Oligocene)

Laramide (65-75 Ma) granitic plutons

$\square$ Kgp - San Manuel granitic porphyry

Kgc - Copper Creek granitic stock

Kgt - Tortilla quartz diorite

Laramide (60-80 Ma) stratified units

Kaf - American Flag Formation

Kcs - Cascabel Formation

Kgv - Glory Hole Volcanics
Kwv - Williamson Canyon Volcanics

Kbi - Bisbee Group (Lower Cretaceous)

JwV - Walnut Canyon Volcanics (Jurassic)

Ps - Sedimentary strata (Paleozoic)

Yap - Apache Group (Middle Proterozoic)

Yat - Apache Group and Troy Quartzite (Middle Proterozoic)

$\square$ Yor - Oracle Ruin Granite (Middle Proterozoic)

$\square$ Xyg - Granodiorite (Precambrian)

Xjl - Johnny Lyon Granodiorite (Lower Proterozoic)

Xpi - Pinal Schist (Lower Proterozoic)

Figure 2. Explanation for the simplified geologic map of the San Pedro River Basin, Arizona 


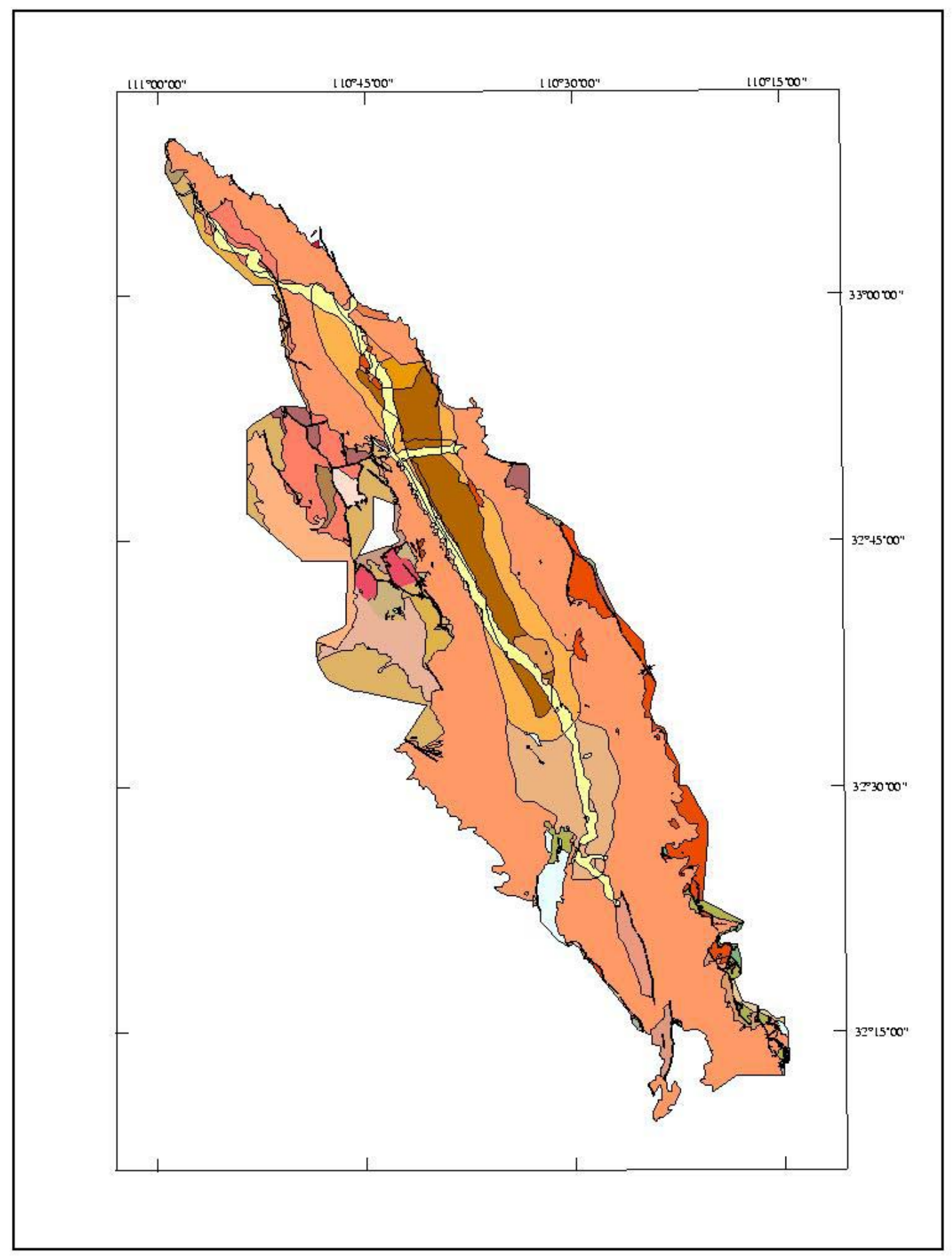

Figure 3. Simplified geologic map the San Pedro River Basin, Arizona. 
Tq Quiburis Formation (Miocene-Pliocene) - Basin fill of San Pedro trough

Tqc Gravelly alluvial-fan and braidplain facies (Upper Miocene to Pliocene(?)Massive to imbricated conglomeratic streamflood and minor debris-flow deposits which flank the central San Pedro trough (San Pedro segment), but occupy the full width of northern San Pedro trough (Gila segment) and of southern San Pedro trough (south of Redington), where paired piedmont fan subfacies flank axial fluvial subfacies not mapped separately).

Tqcr Rubbly bajada facies of the gravelly alluvial-fan and braidfacies (Tqc) of the Quiburis Formation

Tqs Sandy fan-toe, lake-margin, and delta-front sandflat facies-Massive to laminated sandstone with minor shale or mudstone interbeds and local thin pebble stringers which are intermediate in both grain size and depositional environment between laterally equivalent alluvial-fan/brainplain (Tqc) and lacustrine (Tql and Tqm) facies

Tqse Prominent delta-front subfacies of "Eskiminzin Delta"-Sandstone, locally pebbly, with multiple thin mudstone interbeds deposited where the axial fluvial system flowing to the southeast down the Gila segment of the San Pedro trough debouched into the axial lacustrine system of the San Pedro segment of the San Pedro trough near an array of partly buried tiltblocks that expose Galiuro Volcanics near Dudleyville

Tqsr Extensive alluvial plain subfacies ("Redington Member") of sandstone beds - Contains local pebble stringers and lenses, interbedded reddish mudstone partings, and dispersed pedogenic carbonate nodules.

Represents the axial fluvial system occupying the San Pedro trough south of lacustrine-influenced facies (Tql and Tqm), which extend from the Gila River to the "Little Black Hills" near San Manuel

Tqsrg Area of 1-10 cm gypsum stringers in sandstone (Tqsr)

Tqm Massive prodelta mudstone —Deposited as a foredelta facies of "Eskiminzin Delta"

Tql Laminated lacustrine facies - Variably interbedded mudstone, limestone, gypsum, and diatomite with sparse and thin intercalations of laminated lacustrine sandstone

Tqld Diatomaceous facies of the laminated lacustrine facies (Tql) of the Quiburis Formation

Tsm San Manuel Formation (Lower Miocene) - Includes local areally restricted facies (Dickinson, 1991) south of Redington (lateral equivalence of the three southern facies is demonstrated by tongues of Tkse within Tspg as mapped by Dickinson along lower Paige Canyon, and tongues of Tspg within Tssz as mapped by Dickinson along lower Robles Canyon)

Tssz Soza Canyon facies-Volcaniclastic (Galiuro Volcanics clasts)

Tspg Paige Canyon facies-Metamorphiclastic (Laramide metamorphite clasts)

Tske Kelsey Canyon facies-Plutoniclastic (Johnny Lyon Granodiorite clasts) 
Tbw Beehive Well member-Well-bedded to laminated interval of sandstone and conglomeratic sandstone forming medial stratigraphic horizons within San Manuel Formation on the downthrown side of the Cowhead Well Fault

Tsmb Debris-avalanche megabreccia composed of displaced blocks of Yor and Tvy

Tst Tucson Wash Member — with reworked Cloudburst/Galiuro volcaniclast and net paleoflow (imbrication) to S55W $(\mathrm{N}=40)$

Tsk Kanally Member-with mainly granitic (Oracle-Ruin) detritus and net paleoflow (from clast imbrication) to $\mathrm{N} 60-65 \mathrm{E}(\mathrm{N}=20)$

Tvy Olivine-bearing basaltic andesite lava

Trf Rhyodacitic to rhyolitic felsite domes and plugs (Upper Oligocene to Lower Miocene)-Age is syn-Cloudburst, pre-San Manuel

Tcb Cloudburst Formation (Oligocene-Miocene) — Conglomeratic redbeds. Includes lower volcanic ( Galiuro Volcanics) and upper sedimentary members, as well as local map units

Tes Sedimentary upper member-Alluvial fan to braidstream facies with volcanic and granitic clast; net paleoflow (imbrication) to $\mathrm{N} 25 \mathrm{E}(\mathrm{N}=20)$ but to N45W (N=5) south of Black Canyon fault; markerbeds: lb, lava/breccia; vs, volcanic sandstone; tu, silicic tuff (Tes has redbed coloration)

Tch Hackberry Wash facies (Dickinson, 1991) - Located in the Tortilla Mountains southwest of the Gila River segment of the San Pedro trough where volcanic member (Tcv) is absent

Tev Volcanic lower member-Mainly intermediate (andesite-latite) but also mafic and silicic (basalt, dacite) lava, flow-breccia, and varied volcaniclastic rocks

Tgv Galiuro Volcanics (Oligocene-Miocene)_-Lateral equivalent of Cloudburst Formation

Tmi Mineta Formation (Oligocene) — Redbeds

Laramide (65-75 Ma) granitic plutons (small intrusive bodies not shown)

Kgp San Manuel granitic porphyry

Kgc Copper Creek granitic stock

Kgt Tortilla quartz diorite

Laramide (60-80 Ma) stratified units (lateral correlations uncertain) 

Kaf American Flag Formation
Kes Cascabel Formation
Kgv Glory Hole Volcanics
Kwv Williamson Canyon Volcanics
Kbi Bisbee Group (Lower Cretaceous)
Jwv Walnut Canyon Volcanics (Jurassic)
Pzs Sedimentary strata (Paleozoic)
Yap Apache Group (Middle Proterozoic) - Intruded locally by 1100 Ma diabase sills and dikes not shown separately
Yat Apache Group and Troy Quartzite, undifferentiated — Intruded locally by 1100 Ma diabase sills not shown separately
Yor Oracle-Ruin Granite (Middle Proterozoic, 1420-1450 Ma)—megacrystic
XYg Granodiorite (Precambrian) —Equigranular, probably a mafic phase of Oracle- Ruin Granite, but possibly related to older Madera Diorite (1625-1700 Ma)
Xjl Johnny Lyon Granodiorite (Lower Proterozoic, 1625 Ma)
Xpi Pinal Schist (Lower Proterozoic, $>1700 \mathrm{Ma}$ )

\section{Data Sources, Processing, and Accuracy}

The original mylars of twelve 1:24,000-scale maps of the study area (Dickinson, 1993, 1998, 2000) were scanned by G. Stephen Pitts on a Scanographics CF500/4 scanner using ScanServ 3.5.1 software. Pitts mathematically generated a tic file with tics of the study area spaced at 2.5-minute intervals, and Karen Bolm rectified the scanned images using ESRI ArcView Image Analysis. Bolm and Tasha Lewis digitized the linework in ArcView (ver. 3.2) and attributed the lines and polygons. The digital files were then converted to ArcInfo (ver. 7.2) format, augumented with an interim geologic map data model (data base), further attributed and edited, and then plotted and compared to the original geologic maps to check for digitizing and attributing errors.

When the digital geologic maps were plotted and compared to the mylar originals (Dickinson, 1993, 1998, 2000), the authors discovered considerable north/south 
distortion in the set of ten maps (Dickinson, 1998). A comparison of the mylars with their corresponding 1:24,000-scale base maps revealed a similar north/south distortion in the mylars. The authors concluded that the mylars probably stretched from being repeatedly run through a hot, roll-feed copy machine to make copies of the map for sale. Due to this distortion, it is difficult to estimate the accuracy of the Dickinson (1998) portion of the digital database. The horizontal accuracy of linear features is estimated to be within 24 meters. This digital database is not meant to be used at any scale larger than $1: 24,000$ (for example 1:12,000 or 1:2,000).

\section{GIS Documentation}

The digital geologic map of the Quiburis Formation and surrounding area includes a geologic linework arc attribute table, QUIB24K.AAT, that relates to the QUIB24K.CO3, QUIB24K.ST3, QUIB24K.LGU, and QUIB24K.REF files; a rock unit polygon attribute table, QUIB24K.PAT, that relates to the QUIB24K.RU and QUIB24K.REF files; and a geologic map symbol point attribute table, QUIB24KP.PAT, that relates to the QUIB24KP.SYM and QUIB24KP.REF files (see fig. 4). These data files are described below.

\section{Linear Features}

Descriptions of the items identifying linear features such as contacts, boundaries (for example, lines of latitude and longitude, state boundaries) and structures in the arc (or line) attribute table, QUIB24K.AAT, are as follows:

\begin{tabular}{|l|l|l|l|}
\hline \multicolumn{2}{|l|}{ QUIB24K.AAT } \\
\hline $\begin{array}{l}\text { ITEM } \\
\text { NAME }\end{array}$ & $\begin{array}{l}\text { ITEM } \\
\text { TYPE }\end{array}$ & $\begin{array}{l}\text { ITEM } \\
\text { LENGTH }\end{array}$ & ATTRIBUTE DESCRIPTION \\
\hline linecode & integer & 3 & $\begin{array}{l}\text { Numeric code used to identify type of linear feature. } \\
\text { Linecodes }<100 \text { are used for contacts and boundaries } \\
\text { which are described in the QUIB24K.CO3 file. } \\
\text { Linecodes }>100 \text { and }<600 \text { represent structural features } \\
\text { which are described in the QUIB24K.ST3 file. } \\
\text { Linecodes }>800 \text { and }<900 \text { represent linear geologic } \\
\text { units which are described in QUIB24K.LGU }\end{array}$ \\
\hline name & character & 36 & Name given to structural feature. \\
\hline source & integer & 4 & $\begin{array}{l}\text { Numeric code used to identify the data source for the } \\
\text { linear feature. Complete references for the sources are } \\
\text { listed in the QUIB24K.REF file. }\end{array}$ \\
\hline desc & character & 100 & Written description of feature \\
\hline
\end{tabular}


Arc attribute table and related look-up tables:

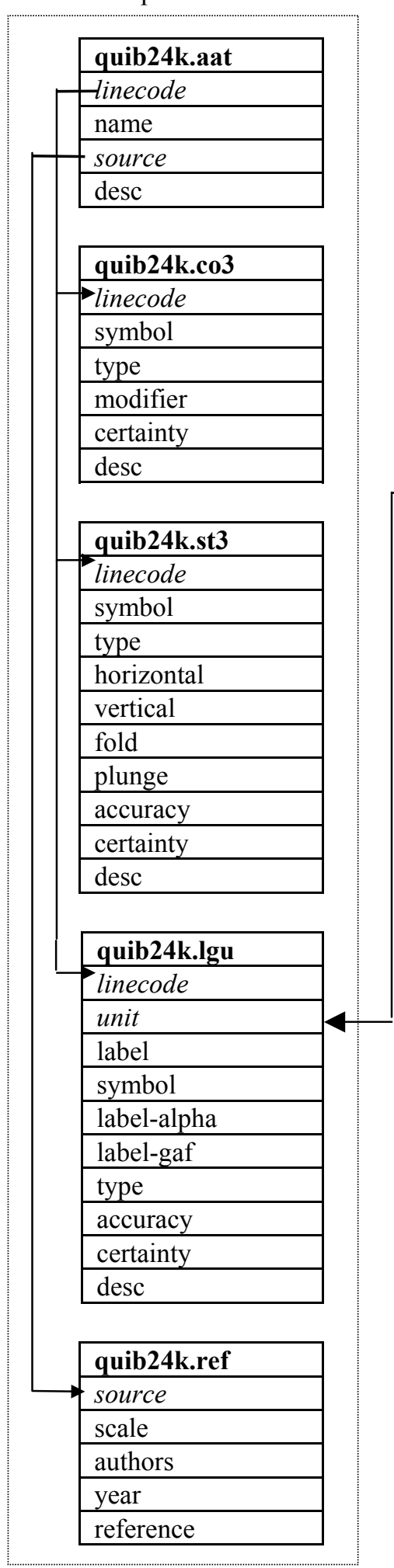

Polygon attribute table and related look-up tables:

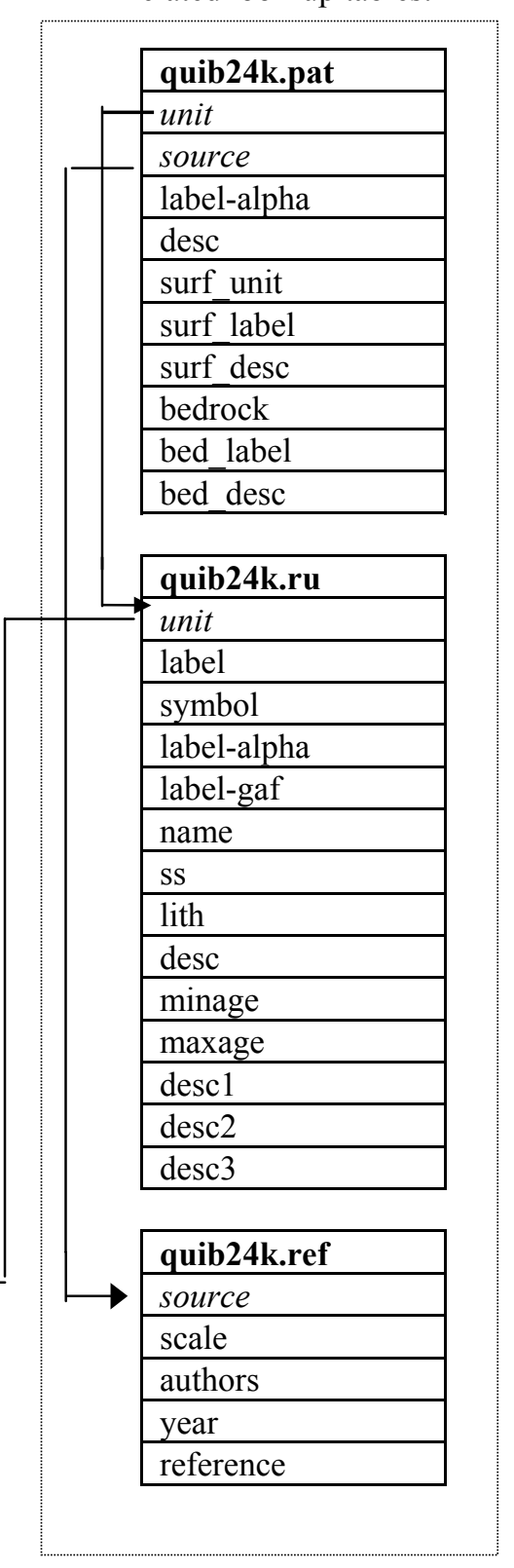

Point attribute table and related look-up tables:

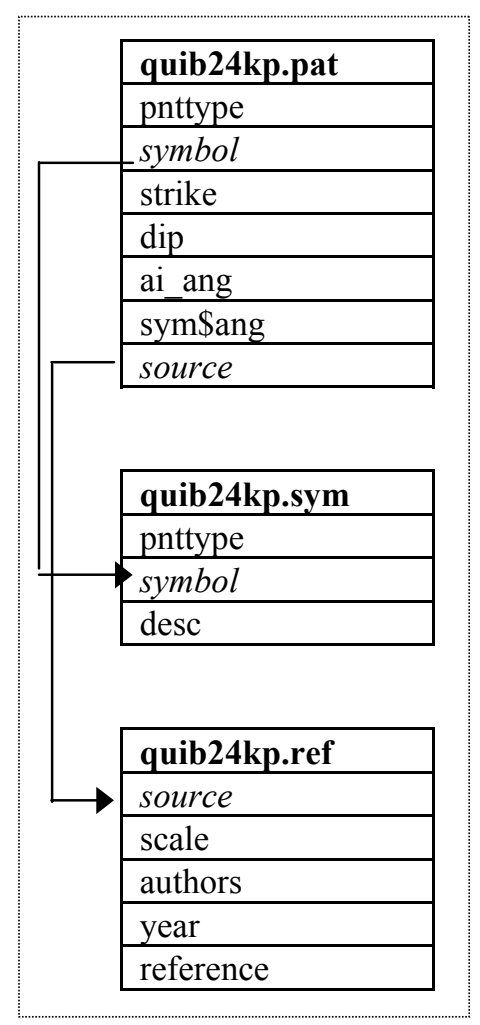

Figure 4: Relationships between feature attribute tables and look-up tables. 
Attribute descriptions for items in the contact (and boundary) look-up table, QUIB24K.CO3 (for use with the GEOL DIA.LIN lineset), are as follows:

\begin{tabular}{|l|l|l|l|}
\hline \multicolumn{2}{|l|}{ QUIB24K.CO3 } \\
\hline ITEM & $\begin{array}{l}\text { ITEM } \\
\text { TYPE }\end{array}$ & $\begin{array}{l}\text { ITEM } \\
\text { LENGTH }\end{array}$ & ATTRIBUTE DESCRIPTION \\
\hline linecode & integer & 3 & $\begin{array}{l}\text { Numeric code (a value < 100) used to identify type of contact } \\
\text { or boundary. (This item also occurs in QUIB24K.AAT.) }\end{array}$ \\
\hline symbol & integer & 3 & $\begin{array}{l}\text { Line symbol number used by Arc/Info to plot lines. } \\
\text { Symbol numbers refer to the GEOL_DIA.LIN lineset. }\end{array}$ \\
\hline type & character & 10 & $\begin{array}{l}\text { Major type of line, for example, contact, state boundaries, } \\
\text { lines of latitude and longitude used for neatlines. }\end{array}$ \\
\hline modifier & character & 20 & $\begin{array}{l}\text { Line type modifier, for example, approximate, concealed, } \\
\text { gradational. No entry implies 'known.' }\end{array}$ \\
\hline certainty & character & 15 & $\begin{array}{l}\text { Degree of certainty of contact or boundary, for example, } \\
\text { inferred, uncertain. No entry implies 'certain.' }\end{array}$ \\
\hline desc & character & 100 & Written description or explanation of contact or boundary. \\
\hline
\end{tabular}

Attribute descriptions for items in the structure look-up table, QUIB24K.ST3 (for use with the GEOL DIA.LIN lineset), are as follows:

\begin{tabular}{|l|l|l|l|}
\hline \multicolumn{2}{|l|}{ QUIB24K.ST3 } \\
\hline $\begin{array}{l}\text { ITEM } \\
\text { NAME }\end{array}$ & $\begin{array}{l}\text { ITEM } \\
\text { TYPE }\end{array}$ & $\begin{array}{l}\text { ITEM } \\
\text { LENGTH }\end{array}$ & ATTRIBUTE DESCRIPTION \\
\hline linecode & integer & 3 & $\begin{array}{l}\text { Numeric code (a value > 100 and < 600) used to identify type } \\
\text { of structural feature. (This item also occurs in } \\
\text { QUIB24K.AAT.) }\end{array}$ \\
\hline symbol & integer & 3 & $\begin{array}{l}\text { Line symbol number used by ArcInfo to plot arc (line). } \\
\text { Symbol numbers refer to the GEOL_DIA.LIN lineset. }\end{array}$ \\
\hline type & character & 10 & $\begin{array}{l}\text { Major type of structure, for example, fault, fracture, fold, } \\
\text { other. }\end{array}$ \\
\hline horizontal & character & 20 & $\begin{array}{l}\text { Type of horizontal fault movement, for example, left-lateral, } \\
\text { right-lateral. No entry implies 'unknown.' }\end{array}$ \\
\hline fold & character & 20 & $\begin{array}{l}\text { Type of vertical fault movement, for example, normal. No } \\
\text { entry implies 'unknown.' }\end{array}$ \\
\hline plunge & character & 15 & Type of fold, for example, anticline, syncline. \\
\hline accuracy & character & 15 & $\begin{array}{l}\text { Type of plunge on fold, for example, horizontal, plunging, } \\
\text { plunging in, plunging out. }\end{array}$ \\
\hline certainty & character & 15 & $\begin{array}{l}\text { Line type modifier indicating degree of accuracy, for example, } \\
\text { approximately located, concealed, gradational. No entry } \\
\text { implies 'known.' }\end{array}$ \\
\hline desc & character & 100 & $\begin{array}{l}\text { Degree of certainty of contact or boundary, for example, } \\
\text { inferred, uncertain. No entry implies 'certain.' }\end{array}$ \\
\hline
\end{tabular}


Attribute descriptions for items in the linear geologic unit look-up table, QUIB24K.LGU (for use with the GEOL DIA.LIN lineset), are as follows:

\begin{tabular}{|l|l|l|l|}
\hline QUIB24K.LGU & \multicolumn{2}{|l|}{} \\
\hline $\begin{array}{l}\text { ITEM } \\
\text { NAME }\end{array}$ & $\begin{array}{l}\text { ITEM } \\
\text { TYPE }\end{array}$ & $\begin{array}{l}\text { ITEM } \\
\text { LENGTH }\end{array}$ & ATTRIBUTE DESCRIPTION \\
\hline linecode & integer & 3 & $\begin{array}{l}\text { Numeric code (a value > 800 and < 900) used to identify type } \\
\text { of structural feature. (This item also occurs in } \\
\text { QUIB24K.AAT.) }\end{array}$ \\
\hline unit & integer & 4 & $\begin{array}{l}\text { Numeric code used to identify the rock unit which is described } \\
\text { in the QUIB24K.RU look-up table. (This item also occurs in } \\
\text { QUIB24K.RU.) }\end{array}$ \\
\hline label & character & 10 & $\begin{array}{l}\text { Rock unit label (abbreviation) used to label unit on map. } \\
\text { (This item is also located in the QUIB24K.RU look-up table.) }\end{array}$ \\
\hline symbol & integer & 3 & $\begin{array}{l}\text { Line symbol used by ArcInfo to plot arc (line). Symbol } \\
\text { numbers refer to the GEOL_DIA.LIN lineset. }\end{array}$ \\
\hline label-alpha & character & 10 & Rock unit label (abbreviation) \\
\hline type & character & 10 & $\begin{array}{l}\text { Rock unit label (abbreviation) that uses the GeoAgeFullAlpha } \\
\text { font, ver. 1.1 (Richard Koch, personal commun., 2001) }\end{array}$ \\
\hline accuracy & character & 10 & $\begin{array}{l}\text { Major type of line, for example, contact, state boundaries, } \\
\text { lines of latitude and longitude used for neatlines }\end{array}$ \\
\hline certainty & character & 15 & $\begin{array}{l}\text { Line type modifier indicating degree of accuracy, for example, } \\
\text { approximately located, concealed, gradational. No entry } \\
\text { implies 'known.' }\end{array}$ \\
\hline desc & character & 100 & $\begin{array}{l}\text { Degree of certainty of contact or boundary, for example, } \\
\text { inferred, uncertain. No entry implies 'certain.' }\end{array}$ \\
Written description or explanation of linear geologic unit. \\
\hline
\end{tabular}




\section{Areal Features}

Descriptions of the items identifying geologic units in the polygon attribute table, QUIB24K.PAT, are as follows:

\begin{tabular}{|c|c|c|c|}
\hline \multicolumn{4}{|c|}{ QUIB24K.PAT } \\
\hline $\begin{array}{l}\text { ITEM } \\
\text { NAME }\end{array}$ & $\begin{array}{l}\text { ITEM } \\
\text { TYPE }\end{array}$ & $\begin{array}{l}\text { ITEM } \\
\text { LENGTH }\end{array}$ & ATTRIBUTE DESCRIPTION \\
\hline unit & integer & 4 & $\begin{array}{l}\text { Numeric code used to identify the rock unit which is described in } \\
\text { the QUIB24K.RU look-up table. (This item also occurs in the } \\
\text { QUIB24K.RU look-up table.) }\end{array}$ \\
\hline source & integer & 4 & $\begin{array}{l}\text { Numeric code used to identify the data source for the rock unit. } \\
\text { Complete references for the sources are listed in the } \\
\text { QUIB24KK.REF file. }\end{array}$ \\
\hline label-alpha & character & 10 & $\begin{array}{l}\text { Rock unit label (abbreviation) used to label unit on map using } \\
\text { standard alpha characters. (This item was joined from the } \\
\text { QUIB24K.RU look-up table.) }\end{array}$ \\
\hline $\operatorname{desc}$ & character & 250 & $\begin{array}{l}\text { Formal or informal unit name. (This item was joined from the } \\
\text { QUIB24K.RU look-up table.) }\end{array}$ \\
\hline surf_unit & integer & 4 & $\begin{array}{l}\text { Numeric code used to identify the surficial rock that is described } \\
\text { in the QUIB24K.RU look-up table under the item } \text { unit. (The item } \\
\text { surf_unit does not occur in QUIB24K.RU.) The attribute values } \\
\text { for surf_unit are a subset of the attribute values for unit. This } \\
\text { item, surf_unit, is attributed only when the underlying bedrock } \\
\text { has been identified. }\end{array}$ \\
\hline surf_label & character & 10 & Surficial rock unit label (abbreviation). \\
\hline surf_desc & character & 250 & $\begin{array}{l}\text { Formal or informal surficial rock unit name. (This item was } \\
\text { joined from the desc iten in QUIB24K.RU look-up table) }\end{array}$ \\
\hline bedrock & integer & 4 & $\begin{array}{l}\text { Numeric code used to identify the bedrock that is described in the } \\
\text { QUIB24K.RU look-up table under the item unit. (The item } \\
\text { bedrock does not occur in QUIG24K.RU.) The attribute values } \\
\text { for bedrock are a subset of the attribute values for unit. This } \\
\text { item, bedrock, is attributed only when the underlying bedrock has } \\
\text { been identified. }\end{array}$ \\
\hline bed_label & character & 10 & Bedrock unit label (abbreviation). \\
\hline bed_desc & character & 250 & $\begin{array}{l}\text { Formal or informal bedrock unit name. (This item was joined } \\
\text { from the desc item in QUIB24K.RU look-up table. }\end{array}$ \\
\hline
\end{tabular}


Attribute descriptions for items in the lithology (rock unit) look-up table, QUIB24K.RU (for use with the WPGCMYK.SHD shadeset), are as follows:

\begin{tabular}{|c|c|c|c|}
\hline \multicolumn{4}{|c|}{ QUIB24K.RU } \\
\hline $\begin{array}{l}\text { ITEM } \\
\text { NAME }\end{array}$ & $\begin{array}{l}\text { ITEM } \\
\text { TYPE }\end{array}$ & $\begin{array}{l}\text { ITEM } \\
\text { LENGTH }\end{array}$ & ATTRIBUTE DESCRIPTION \\
\hline unit & integer & 4 & $\begin{array}{l}\text { Numeric code used to identify rock unit. (This item also occurs in } \\
\text { QUIB24K.PAT.) }\end{array}$ \\
\hline label & character & 10 & $\begin{array}{l}\text { Rock unit label (abbreviation) used to label unit on map. This } \\
\text { item was calculated equal to 'label-gaf' }\end{array}$ \\
\hline symbol & integer & 3 & $\begin{array}{l}\text { Shadeset symbol number used by ArcInfo to plot a filled/shaded } \\
\text { polygon. The symbol numbers used in this file refer to the } \\
\text { WPGCMYK.SHD shadeset. }\end{array}$ \\
\hline label-alpha & character & 10 & Rock unit label (abbreviation) \\
\hline label-gaf & character & 10 & $\begin{array}{l}\text { Rock unit label (abbreviation) that uses the GeoAgeFullAlpha } \\
\text { font, ver. 1.1 (Richard Koch, personal commun., 2001) }\end{array}$ \\
\hline name & character & 7 & $\begin{array}{l}\text { The prefix portion of the rock unit label that does not include } \\
\text { subscripts. (If subscripting is not used in the original unit label, } \\
\text { then the 'name' entry is the same as the 'label' entry.) }\end{array}$ \\
\hline SS & character & 3 & $\begin{array}{l}\text { The suffix portion of the geologic unit label that includes } \\
\text { subscripts. }\end{array}$ \\
\hline lith & character & 20 & $\begin{array}{l}\text { Major type of lithostratigraphic unit, for example, unconsolidated } \\
\text { sediments, sedimentary rocks, metasedimentary rocks, intrusive } \\
\text { rocks, extrusive rocks, metamorphic rocks, water, ice. }\end{array}$ \\
\hline desc & character & 250 & Formal or informal unit name \\
\hline minage & character & 7 & $\begin{array}{l}\text { Minimum stratigraphic age of lithologic unit, for example, } \\
\text { CRET, TERT, M PROT. }\end{array}$ \\
\hline maxage & character & 7 & Maximum stratigraphic age of lithologic unit \\
\hline desc1 & character & 200 & Detailed description of rock unit \\
\hline $\operatorname{desc} 2$ & character & 200 & $\begin{array}{l}\text { Detailed description of rock unit (continued from desc1, if } \\
\text { needed) }\end{array}$ \\
\hline $\operatorname{desc} 3$ & character & 200 & $\begin{array}{l}\text { Detailed description of rock unit (continued from desc2, if } \\
\text { needed) }\end{array}$ \\
\hline
\end{tabular}




\section{Point Features}

Descriptions of the items identifying geologic map symbols are given in the point attribute table, QUIB24KP.PAT, which is defined as follows:

\begin{tabular}{|c|c|c|c|}
\hline \multicolumn{4}{|c|}{ QUIB24KP.PAT } \\
\hline $\begin{array}{l}\text { ITEM } \\
\text { NAME }\end{array}$ & $\begin{array}{l}\text { ITEM } \\
\text { TYPE }\end{array}$ & $\begin{array}{l}\text { ITEM } \\
\text { LENGTH }\end{array}$ & ATTRIBUTE DESCRIPTION \\
\hline pnttype & character & 50 & $\begin{array}{l}\text { Basic type of geologic point data being represented (for } \\
\text { example, inclined foliation, fault attitude, etc). (This item } \\
\text { also occurs in the QUIB24KP.SYM file.) }\end{array}$ \\
\hline symbol & integer & 3 & $\begin{array}{l}\text { Marker symbol number used by ArcInfo to identify type of } \\
\text { geologic map symbol. Symbol numbers refer to the } \\
\text { SCAMP2D.MRK markerset (Matti and others, 1997). } \\
\text { (This item also occurs in the QUIB24KP.SYM file.) }\end{array}$ \\
\hline strike & integer & 3 & $\begin{array}{l}\text { Strike of bedding, foliation or cleavage. } \\
\text { Strike is an azimuthal angle (measured in degrees from } 0 \text { to } \\
360 \text { in a clockwise direction from North). }\end{array}$ \\
\hline $\operatorname{dip}$ & integer & 2 & $\begin{array}{l}\text { Dip of bedding, foliation or cleavage. This value is an } \\
\text { angle measured (in degrees from } 0 \text { to } 90 \text { ) down from the } \\
\text { horizontal; thus a horizontal dip is } 0 \text { degrees and a vertical } \\
\text { dip is } 90 \text { degrees. }\end{array}$ \\
\hline ai_ang & integer & 4 & $\begin{array}{l}\text { An interim value used to calculate sym\$angle. The various } \\
\text { structural map symbols in the SCAMP2D.MRK markerset } \\
\text { (Matti and others, 1997) had to be rotated by different } \\
\text { amounts to achieve their proper map orientation. } \\
\text { For the strike and dip symbols, ai_ang = strike }-270 \text {. }\end{array}$ \\
\hline sym\$ang & integer & 3 & $\begin{array}{l}\text { The angle used to complete the mathematical rotation of } \\
\text { the structural map symbol to its proper orientation on the } \\
\text { map. The various point symbols in the SCAMP2D.MRK } \\
\text { markerset (after Matti and others, 1997) had to be rotated } \\
\text { by different amounts to achieve their proper map } \\
\text { orientation. This value is the \$angle pseudoitem value for } \\
\text { the point. }\end{array}$ \\
\hline source & integer & 4 & $\begin{array}{l}\text { Numeric code used to identify the data source for the } \\
\text { structural map symbol. Complete references for the } \\
\text { sources are listed in the QUIB24KP.REF file. }\end{array}$ \\
\hline
\end{tabular}


Attribute descriptions for items in the geologic map symbols look-up table, QUIB24KP.SYM, [for use with the SCAMP2D.MRK markerset (Matti and others, 1997)], are as follows:

\begin{tabular}{|l|l|l|l|}
\hline \multicolumn{2}{|l|}{ QUIB24KP.SYM } \\
\hline $\begin{array}{l}\text { ITEM } \\
\text { NAME }\end{array}$ & $\begin{array}{l}\text { ITEM } \\
\text { TYPE }\end{array}$ & $\begin{array}{l}\text { ITEM } \\
\text { LENGTH }\end{array}$ & ATTRIBUTE DESCRIPTION \\
\hline pnttype & character & 50 & $\begin{array}{l}\text { Type of point symbol, for example, strike and dip of } \\
\text { inclined bedding, strike and dip of inclined cleavage. (This } \\
\text { item also occurs in the QUIB24KP.PAT file.) }\end{array}$ \\
\hline symbol & integer & 3 & $\begin{array}{l}\text { Marker symbol number used by ArcInfo to identify type of } \\
\text { structural map symbol. Symbol numbers refer to the } \\
\text { SCAMP2D.MRK markerset (Matti and others, 1997). }\end{array}$ \\
\hline desc & character & 250 & Written description or explanation of map symbol. \\
\hline
\end{tabular}

\section{Source Attributes}

Descriptive source or reference information for the QUIB24K and QUIB24KP ArcInfo datasets is stored in the QUIB24K.REF and QUIB24KP.REF files, respectively. Attribute descriptions for items in the QUIB24K.REF and QUIB24KP.REF data source files are as follows:

\begin{tabular}{|l|l|l|l|}
\hline \multicolumn{3}{|l|}{ QUIB24K.REF / QUIB24KP.REF } \\
\hline $\begin{array}{l}\text { ITEM } \\
\text { NAME }\end{array}$ & $\begin{array}{l}\text { ITEM } \\
\text { TYPE }\end{array}$ & $\begin{array}{l}\text { ITEM } \\
\text { LENGTH }\end{array}$ & ATTRIBUTE DESCRIPTION \\
\hline source & integer & 4 & $\begin{array}{l}\text { Numeric code used to identify the data source. (This item } \\
\text { also occurs in the QUIB24K.AAT, QUIB24K.PAT, and } \\
\text { QUIB24KP.PAT files.) }\end{array}$ \\
\hline scale & integer & 8 & $\begin{array}{l}\text { Scale of source map. (This value is the denominator of the } \\
\text { proportional fraction that identifies the scale of the map } \\
\text { that was digitized or scanned to produce the digital map.) }\end{array}$ \\
\hline authors & character & 200 & $\begin{array}{l}\text { Author(s) or compiler(s) of source map entered as last } \\
\text { name, first name or initial, and middle initial. }\end{array}$ \\
\hline year & integer & 4 & Source (map) publication date \\
\hline reference & character & 250 & Remainder of reference in USGS reference format. \\
\hline
\end{tabular}




\section{Obtaining Digital Data}

The complete digital version of the geologic map is available in ArcInfo interchange format with associated data files. These data are maintained in a Universal Transverse Mercator (UTM) map projection (QUIB24K):

Projection: UTM

Zone: $\quad 12$

Units: meters

Datum: NAD27

and in a geographic reference system (latitude and longitude) (QUIB24KG):

Projection: geographic

Units: $\quad$ decimal degrees

Datum: $\quad$ NAD27

To obtain copies of the digital data, do one of the following:

- Download the digital files from the USGS public access World Wide Web site on the Internet: URL = http://geopubs.wr.usgs.gov/open-file/of02-393/ OR

- Anonymous FTP from geopubs.wr.usgs.gov, in the directory pub/open-file/of02$393 /$

These Internet sites contain the spatial digital database and metadata for the geologic map of the Quiburis Formation and surrounding units as ArcInfo exchange-format files (see listing of files in Appendix A). Formatted metadata (Federal Geographic Data Committee-compliant) is included as Appendix B.

To manipulate these data in a geographic information system (GIS), you must have a GIS that is capable of reading ArcInfo interchange-format files.

\section{Obtaining Paper Maps}

Paper copies of the digital geologic map are not available from the U.S Geological Survey. However, with access to the Internet and access to large-format color plotter that can interpret PDF (portable document format) files, 1:125,000-scale paper copies can be made. The database includes the entire area of the twelve 1:24,000-scale map sheets in the original publications (Dickinson 1993, 1998, 2000); however, a single plot at $1: 24,000$ would be too large for a plotter. Hence a single plot at 1:125,000 (quib24k_map.pdf) has been made which approximates the extent of the original map sheets.

1. Download the digital version of the map sheet, quib24k_map.pdf from the USGS public access World Wide Web site on the Internet using the URL $=$ http://geopubs.wr.usgs.gov/open-file/of02-393/

or

2. Anonymous FTP the plot files listed above from geopubs.wr.usgs.gov, in the directory pub/open-file/of02-393/ 
The sheet is formatted to fit on a 36 -inch by-48 inch sheet.

Paper copies of the map can also be created by obtaining the digital files described in the previous section and then creating a plot file in a GIS.

\section{References Cited}

Dickinson, W.R., 1991, Tectonic setting of faulted Tertiary strata associated with the Catalina cone complex in southern Arizona: Geological Society of America Special Paper 264, 106 p.

Dickinson, W.R., 1993, Summary geologic map of Black Hills near Mammoth, Pinal County, Arizona: Tucson, Arizona Geological Survey Contributed Map CM-93-B, scale 1:24,000.

Dickinson, W.R., 1998, Facies map of post-mid-Miocene Quiburis Formation, San Pedro trough, Pinal, Pima, Gila, Graham, and Cochise counties, Arizona: Tucson, Arizona Geological Survey Contributed Map CM-98-A, 10 sheets, scale 1:24,000, 6 p. text.

Dickinson, W.R., 2000, Summary of Tertiary stratigraphic and structural relationships, Camp Grant Wash-Antelope Peak area, Pinal County, Arizona: Tucson, Arizona Geological Survey Contributed Map CM-00-B, scale 1:24,000, 10 p. text.

Matti, J.C., Miller, F.K., Powell, R.E., Kennedy, S.A., Bunyapanasarn, T.P., Koukladas, C., Hauser, R.M., and Cossette, P.M., 1997, Geologic-point attributes for digital geologic-map data bases produced by the Southern California Areal Mapping Project (SCAMP): U.S. Geological Survey Open-File Report 97-859, 7 p. 


\section{Appendix A - List of files in the Quiburis GIS}

--Uncompress the quib24k.tar.Z file and extract the files from the resultant quib24k.tar file.

--Use the 'importfile.aml' to IMPORT all of the *.E00 files for use in ArcInfo.

Primary ArcInfo exchange-format (*.e00) and metadata (*.met) files for the spatial digital databases:

- quib24k.e00 - line and poly GIS (contacts, faults, folds, and map units) in UTM projection

- quib24kg.e00 - line and poly GIS (contacts, faults, folds, and map units) in a geographic reference system (latitude and longitude)

- quib24kp.e00 - point GIS (structural data such as strike and dips, and fault attitudes) in UTM projection

- quib24kpg.e00 - point GIS (structural data such as strike and dips, and fault attitudes) in a geographic reference system (latitude and longitude)

- $\quad$ quib24k.met - metadata

Files in this package have been attributed to produce plots using the shade, line, and marker sets listed below. These sets are included for the user's convenience.

- fnt026.e00 - font

- fnt037.e00 - font

- geoafa_.fon - font file

- geoafa_.pfb-font file

- geol_dia.lin.e00-lineset

- wpgcmyk.shd.e00 - shadeset

- scamp2d.mrk.e00 - markerset

Special geographic characters used in unit designations are from the Geoage font group and may be obtained at the following web site:

Server:

UserID:

Password:

Directory: onyx.wr.usgs.gov

anonymous

your e-mail address

pub/wpg/supplies/geoage_1.1 and

pub/wpg/supplies/geoage_1.2

The following portable document format (.pdf) files are included in the data set: 
- of02-393.pdf

- quib24k_map.pdf report text

digital map sheet (plotted at 1:125,000) Not all point data are included on the map because of the density of the points and the reduced scale of the map. 


\section{Appendix B - Metadata file (quib24k.met) for the Quiburis GIS}

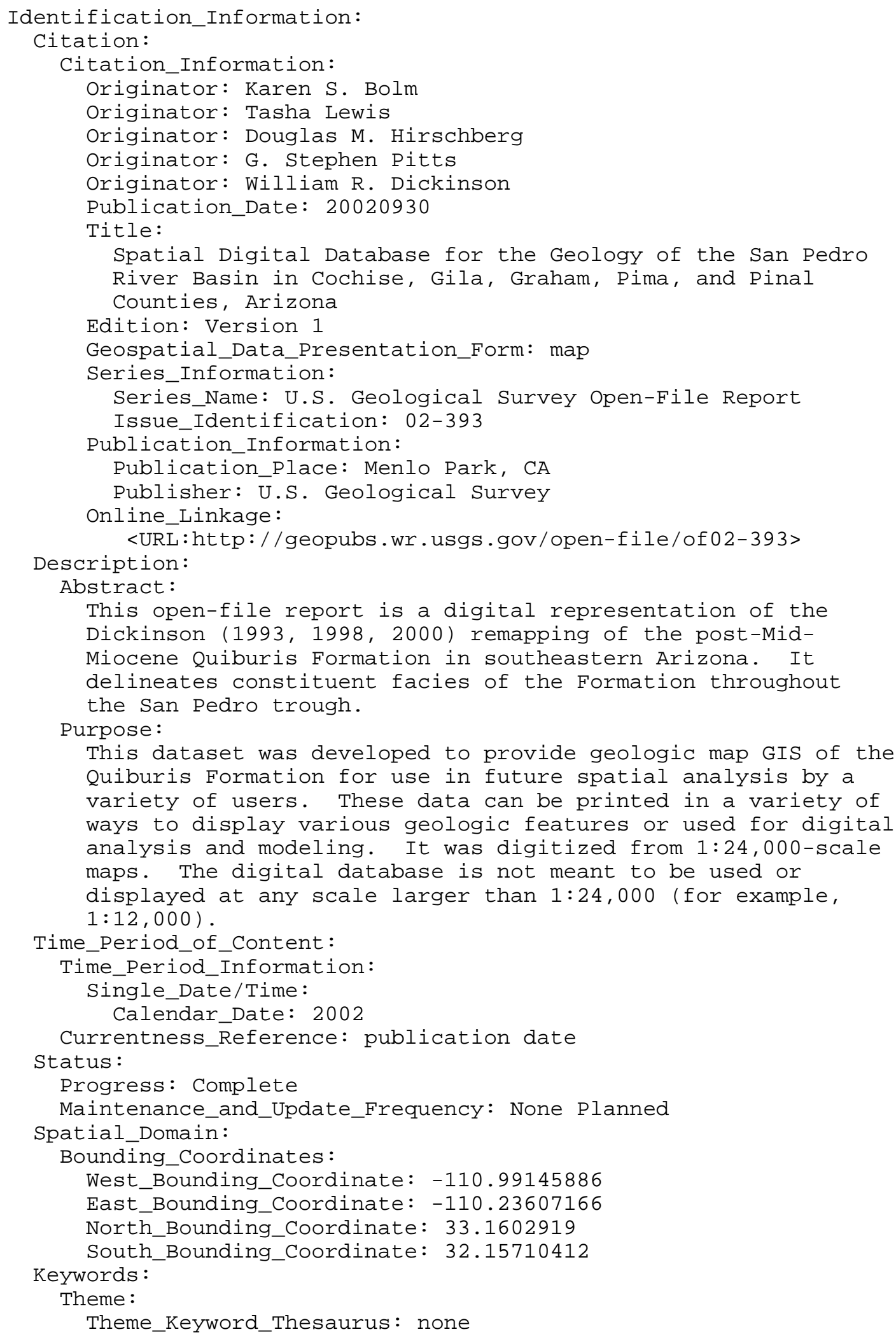


Appendix B

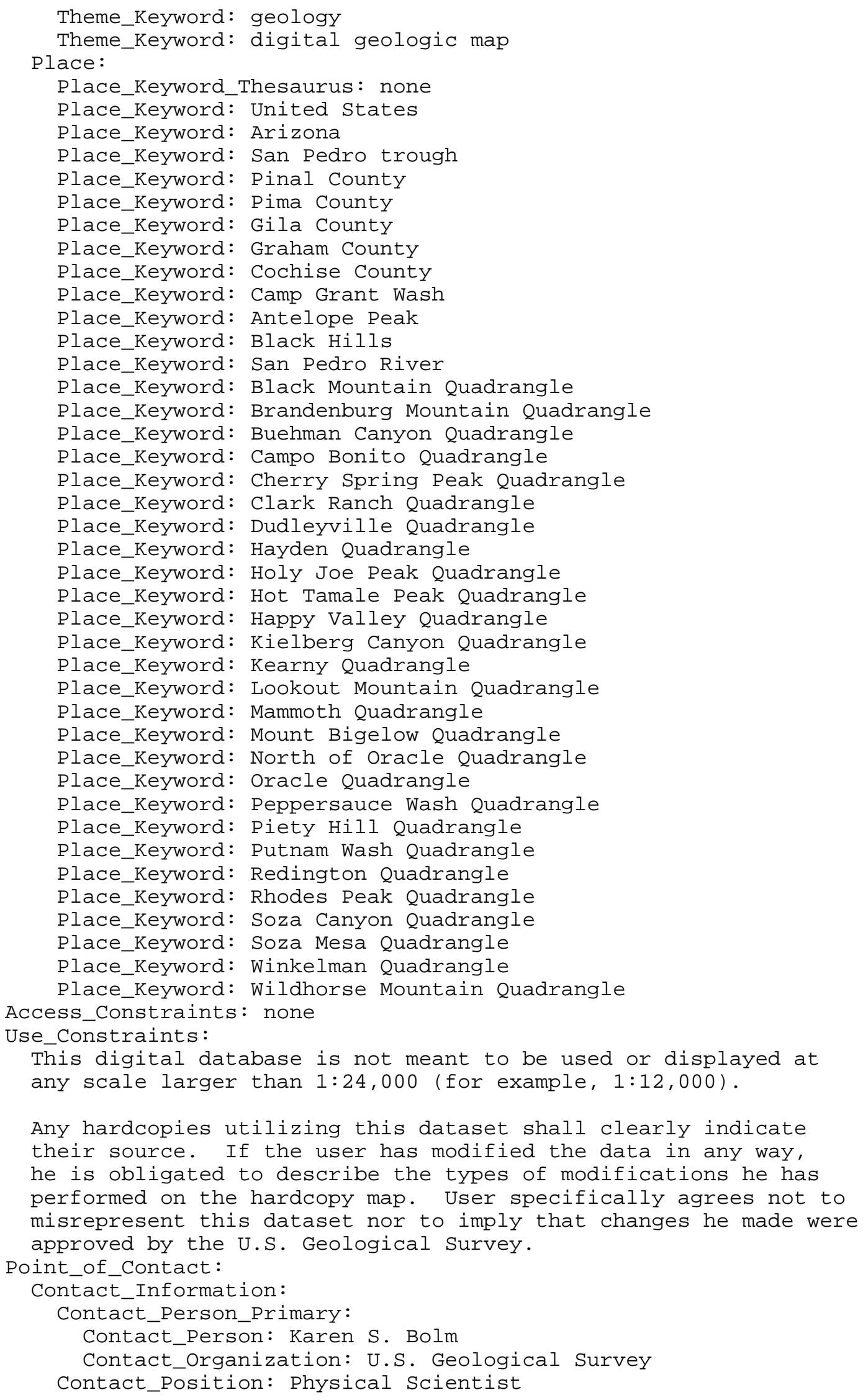




\author{
Contact_Address: \\ Address_type: mailing and physical address \\ Address: 520 North Park Avenue \#355 \\ City: Tucson \\ State_or_Province: AZ \\ Postal_Code: 85719 \\ Country: USA \\ Contact_Voice_Telephone: (520) 670-5544 \\ Contact_Facsimile_Telephone: (520) 670-5113 \\ Contact_Electronic_Mail_Address: kbolm@usgs.gov \\ Data_Set_Credit: \\ Karen $\bar{S}$. Bolm and Tasha Lewis digitized these data from scans of \\ the Dickinson (1993, 1998, 2000) maps made by G. Stephen Pitts. \\ Douglas M. Hirschberg provided programs to aid in attribution \\ of the data, and William R. Dickinson provided attribute \\ information, assisted in the editing, and resolved problems \\ resulting from the combination of three maps. \\ Native_Data_Set_Environment: \\ SunOS, 5.6, sun4u UNIX \\ ARCINFO version 7.2.1 \\ ARCINFO version 8.1 \\ ArcView version 3.2 for Windows \\ Data_Quality_Information: \\ Attribute_Accuracy: \\ Attribute_Accuracy_Report: \\ When the digitized maps were printed and compared to the \\ Dickinson (1998) mylar originals, a considerable north/south \\ distortion was discovered. The mylar originals were compared \\ to topographic maps of the same area and it was determined \\ that the distortion was due to the mylars becoming stretched \\ during repetitive copy processing. Because of this distortion \\ of the Dickinson(1998) maps, it is difficult to estimate \\ the accuracy of this digital map. \\ Accuracy of the digitized versions of the Dickinson (1993, 2000) \\ maps was verified by manual comparison of the source with hard \\ copy printouts and plots and with screen images. \\ Logical_Consistency_Report: \\ Polygon and chain-node topology present. \\ The Dickinson (1993, 1998, 2000) maps were digitized by Karen S. \\ Bolm and Tasha Lewis. Attributes have the same meaning throughout \\ the maps. In some cases, however, units and lines symbols were \\ not consistent from one map to the other. In those cases, one \\ attribute had to be chosen over the other. \\ Completeness_Report: \\ Some of the units at the edge of the Dickinson (1993, 1998, \\ 2000) maps were labeled, but accurate contacts were not \\ defined. In those cases, either units were attributed as \\ "unmapped" or not included on the digital version or new \\ contacts were added by William R. Dickinson. Some labeling, \\ which could not be easily included as attribution, was omitted. \\ Also, some of the symbolization chosen for this dataset is \\ different than that used by Dickinson (1993, 1998, 2000). This \\ was done to standardize products. \\ The original Dickinson (1993, 1998, 2000) maps were drawn on \\ topographic background. Digital versions of those topographic
}


maps are not included with this dataset.

Positional_Accuracy:

Horizontal_Positional_Accuracy:

Horizontal_Positional_Accuracy_Report:

Due to distortions in the original maps, it was impossible to

test the accuracy of the digital mapping of the Dickinson (1998)

maps. Based on testing of the the Dickinson (1993, 2000) maps,

it is estimated that the features are accurate to within

24 meters.

Lineage:

Source_Information:

Source_citation:

Citation_Information:

Originator: William R. Dickinson

Publication_Date: 1993

Title:

Summary Geologic Map of the Black Hills near Mammoth; Pinal

County, Arizona

Geospatial_Data_Presentation_Form: map

Series_Information:

Series_Name: Arizona Geological Survey Contributed Map

Issue_Identification: CM-93-B

Publication_Information:

Publication_Place: Tucson, AZ

Publisher: Arizona Geological Survey

Source_Scale_Denominator: 24000

Type_of_Source_Media: mylar

Source_Time_Period_of_Content:

Time_Period_Information:

Single_Date/Time:

Calendar_Date: 1993

Source_Currentness_Reference: publication date

Source_Citation_Abbreviation: Dickinson (1993)

Source_Contribution:

Dickinson (1993) was one of the three sources of geologic

information uesd to compile the QUIB24K database.

Source_Information:

Source_citation:

Citation_Information:

Originator: William R. Dickinson

Publication_Date: 1998

Title:

Facies Map of Post-Mid-Miocene Quiburis Formation, San Pedro Trough, Pinal, Pima, Gila, Graham, and Cochise Counties, Arizona

Geospatial_Data_Presentation_Form: map

Series_Information:

Series_Name: Arizona Geological Survey Contributed Map

Issue_Identification: CM-98-A

Publication_Information:

Publication_Place: Tucson, AZ

Publisher: Arizona Geological Survey

Source_Scale_Denominator: 24000

Type_of_Source_Media: mylar

Source_Time_Period_of_Content:

Time_Period_Information:

Single_Date/Time:

Calendar_Date: 1998 
Appendix B

\author{
Source_Currentness_Reference: publication date \\ Source_Citation_Abbreviation: Dickinson (1998) \\ Source_Contribution: \\ Dickinson (1998) was one of the three sources of geologic \\ information used to compile the QUIB24K database. \\ Source_Information: \\ Source_citation: \\ Citation_Information: \\ Originator: William R. Dickinson \\ Publication_Date: 2000 \\ Title: \\ Summary of Tertiary Stratigraphic and Structural \\ Relationships, Camp Grant-Antelope Peak Area, Pinal \\ County, Arizona \\ Geospatial_Data_Presentation_Form: map \\ Series_Information: \\ Series_Name: Arizona Geological Survey Contributed Map \\ Issue_Identification: CM-00-B \\ Publication_Information: \\ Publication_Place: Tucson, AZ \\ Publisher: Arizona Geological Survey \\ Source_Scale_Denominator: 24000 \\ Type_of_Source_Media: mylar \\ Source_Time_Period_of_Content: \\ Time_Period_Information: \\ Single_Date/Time: \\ Calendar_Date: 2000 \\ Source_Currentness_Reference: publication date \\ Source_Citation_Abbreviation: Dickinson (2000) \\ Source_contribution: \\ Dickinson (2000) was one of the three sources of geologic \\ information uesd to compile the QUIB24K database. \\ Process_Step: \\ Process_Description: \\ Twelve 1:24,000-scale mylar maps that comprise three Dickinson \\ (1993, 1998, 2000) reports were scanned by G. Stephen Pitts \\ on a Scanographics CF500/4 scanner using Scanserv 3.5.1 \\ software. \\ Pitts mathmetically generated a tic file with tics of the study \\ area spaced at 2.5' intervals, and Karen S. Bolm rectified the \\ scanned images using ESRI ArcView Image Analysis. Bolm and \\ Tasha Lewis digitized the linework using Geologic Mapping Tools, \\ An ArcView extension developed by William R. Kelley (contractor \\ At the U.S. Geological Survey's Western Regional Mineral \\ Resources Team, Spokane Field Office). Lines and polygons were \\ Attributed by Bolm in ArcInfo 7.2.1. \\ Points were digitized from the scanned images using digpnt.aml, \\ and attribution was retrieved for annotation using getdip.aml, \\ both programs written by Douglas M. Hirschberg. \\ Process_Date: 2000-2001 \\ Process_step: \\ Process_Description: \\ After review, it was decided to merge the three Dickinson (1993, \\ 1998, 2000) maps into a single spatial digital database. The \\ coverages were merged by Karen S. Bolm, and discrepancies were \\ resolved by her and William R. Dickinson. Some additional \\ contacts had to be added to separate units that were originally \\ on the edges of the mapped areas. Duplicate lines and points \\ were removed. Maps were plotted at 1:24,000 and checked for
}


Appendix B

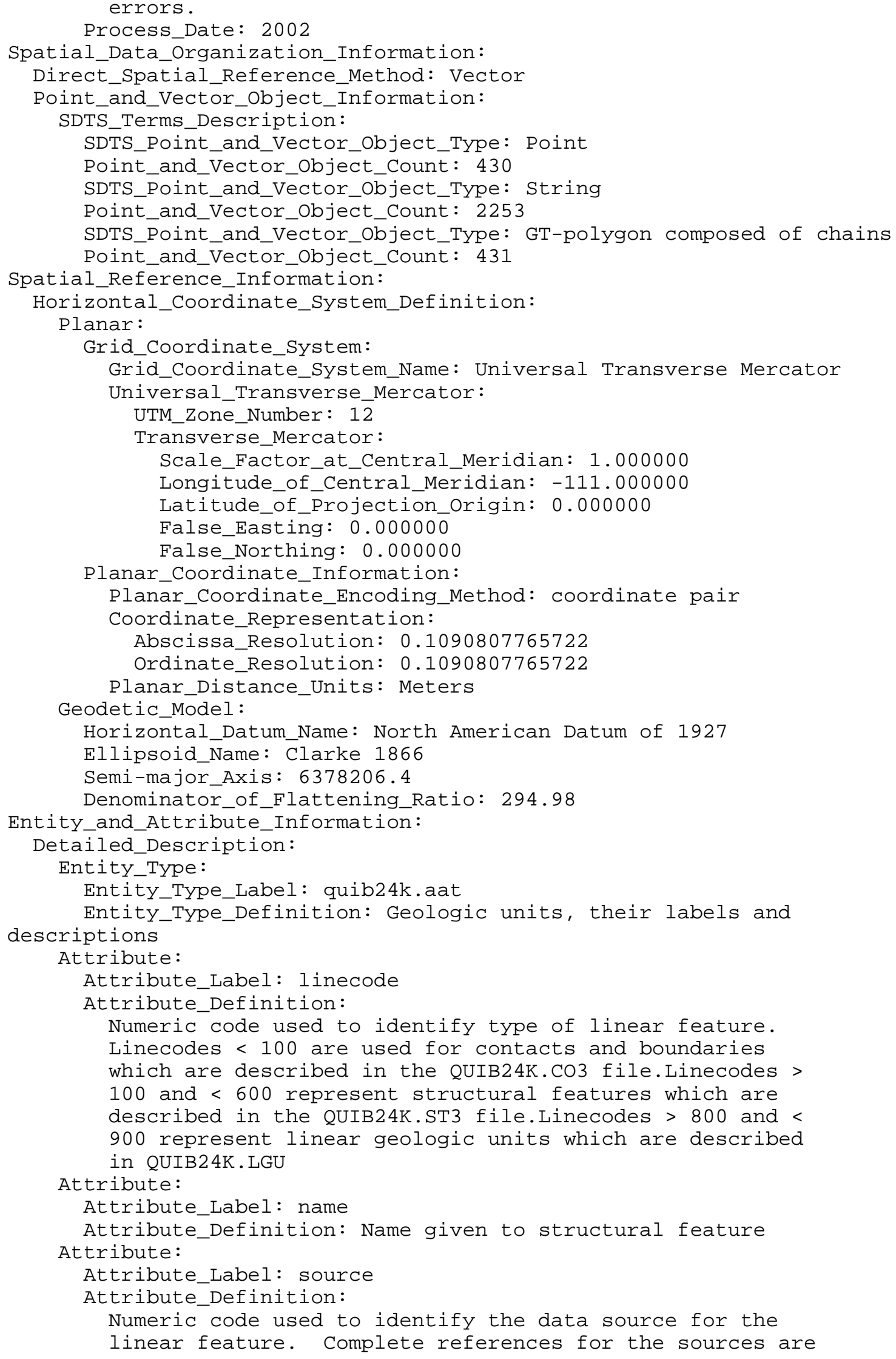




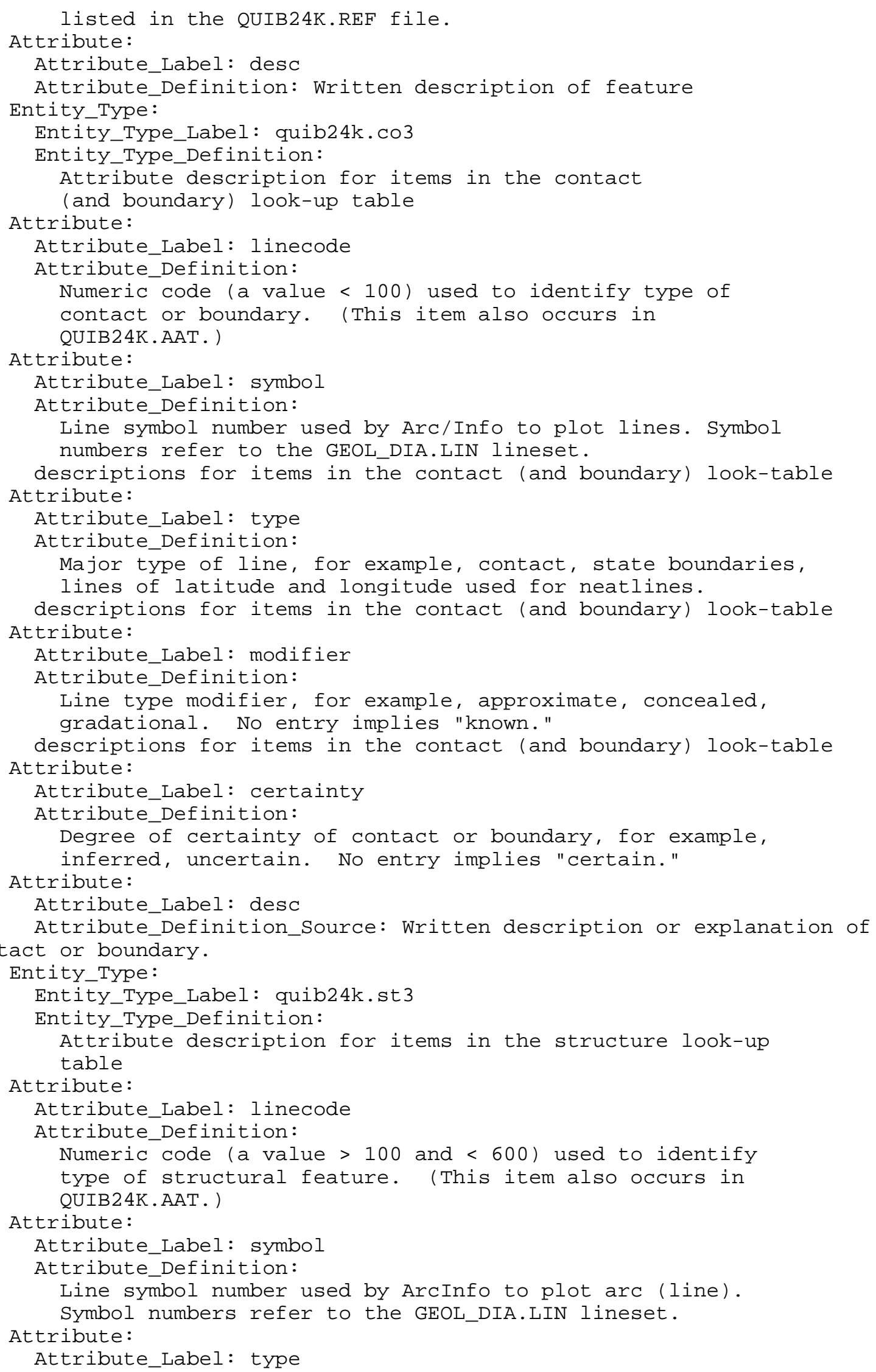


Appendix B

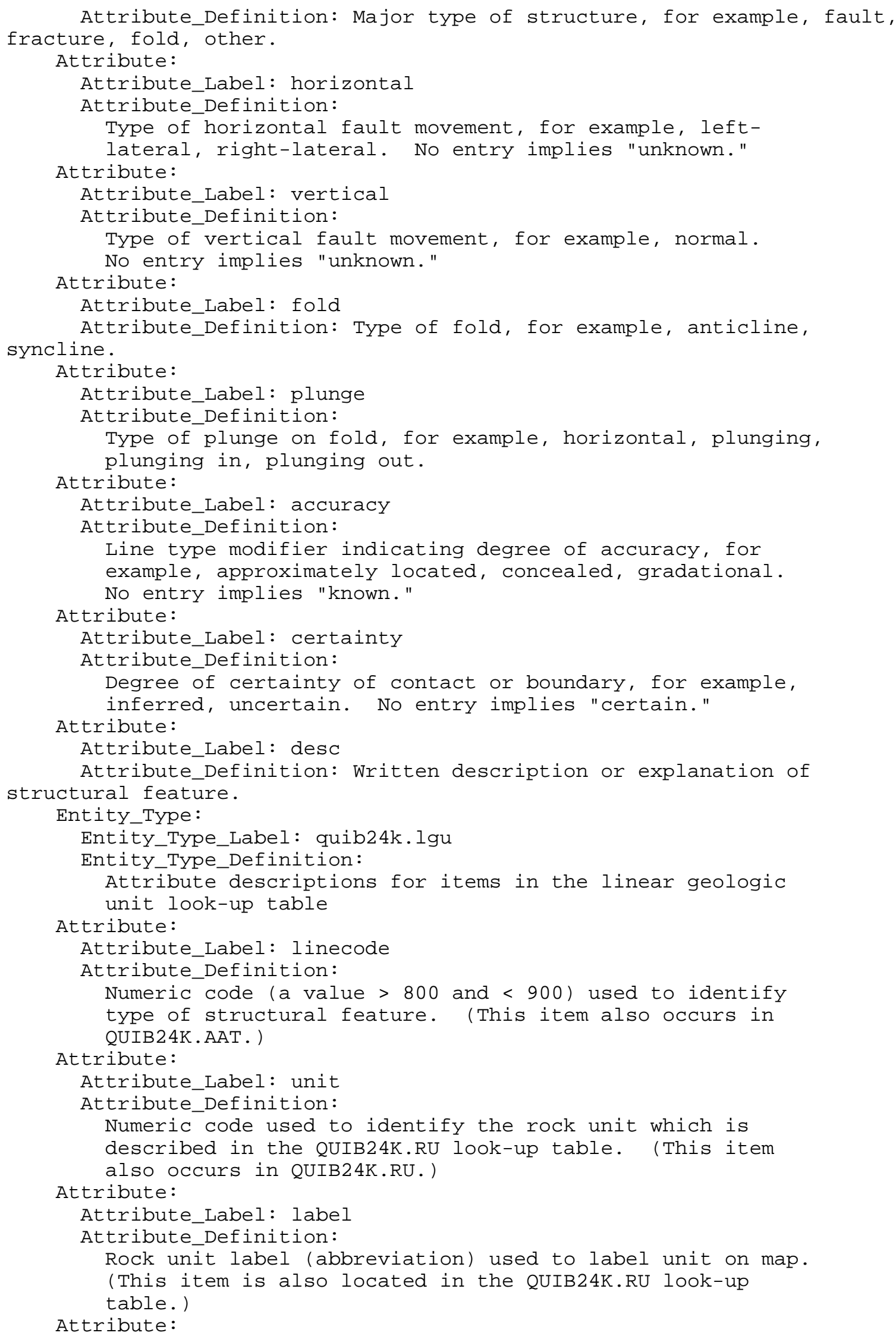


Attribute_Label: symbol

Attribute_Definition:

Line symbol used by ArcInfo to plot arc (line). Symbol

numbers refer to the GEOL_DIA.LIN lineset.

Attribute:

Attribute_Label: label-alpha

Attribute_Definition: Rock unit label (abbreviation)

Attribute:

Attribute_Label: label-gaf

Attribute_Definition:

Rock unit label (abbreviation) that uses the GeoAgeFullAlpha

font, ver. 1.1 (Richard Koch, personal commun., 2001)

Attribute:

Attribute_Label: type

Attribute_Definition:

Major type of line, for example, contact, state boundaries, lines of latitude and longitude used for neatlines

Attribute:

Attribute_Label: accuracy

Attribute_Definition:

Line type modifier indicating degree of accuracy, for example, approximately located, concealed, gradational. No entry implies "known."

Attribute:

Attribute_Label: certainty

Attribute_Definition:

Degree of certainty of contact or boundary, for example, inferred, uncertain. No entry implies "certain."

Attribute:

Attribute_Label: desc

Attribute_Definition:

Written description or explanation of linear geologic unit.

Entity_type:

Entity_Type_Label: quib24k.pat

Entity_Type_Definition:

Descriptions of the items identifying geologic units in the polygon attribute table

Attribute:

Attribute_Label: unit

Attribute_Definition:

Numeric code used to identify the rock unit which is described in the QUIB24K.RU look-up table. (This item also occurs in the QUIB24K.RU look-up table.)

Attribute:

Attribute_Label: source

Attribute_Definition:

Numeric code used to identify the data source for the rock unit. Complete references for the sources are listed in the QUIB24KK.REF file.

Attribute:

Attribute_Label: label-alpha

Attribute_Definition:

Rock unit label (abbreviation) used to label unit on map using standard alpha characters. (This item was joined from the QUIB24K.RU look-up table.)

Attribute:

Attribute_Label: desc

Attribute_Definition: 


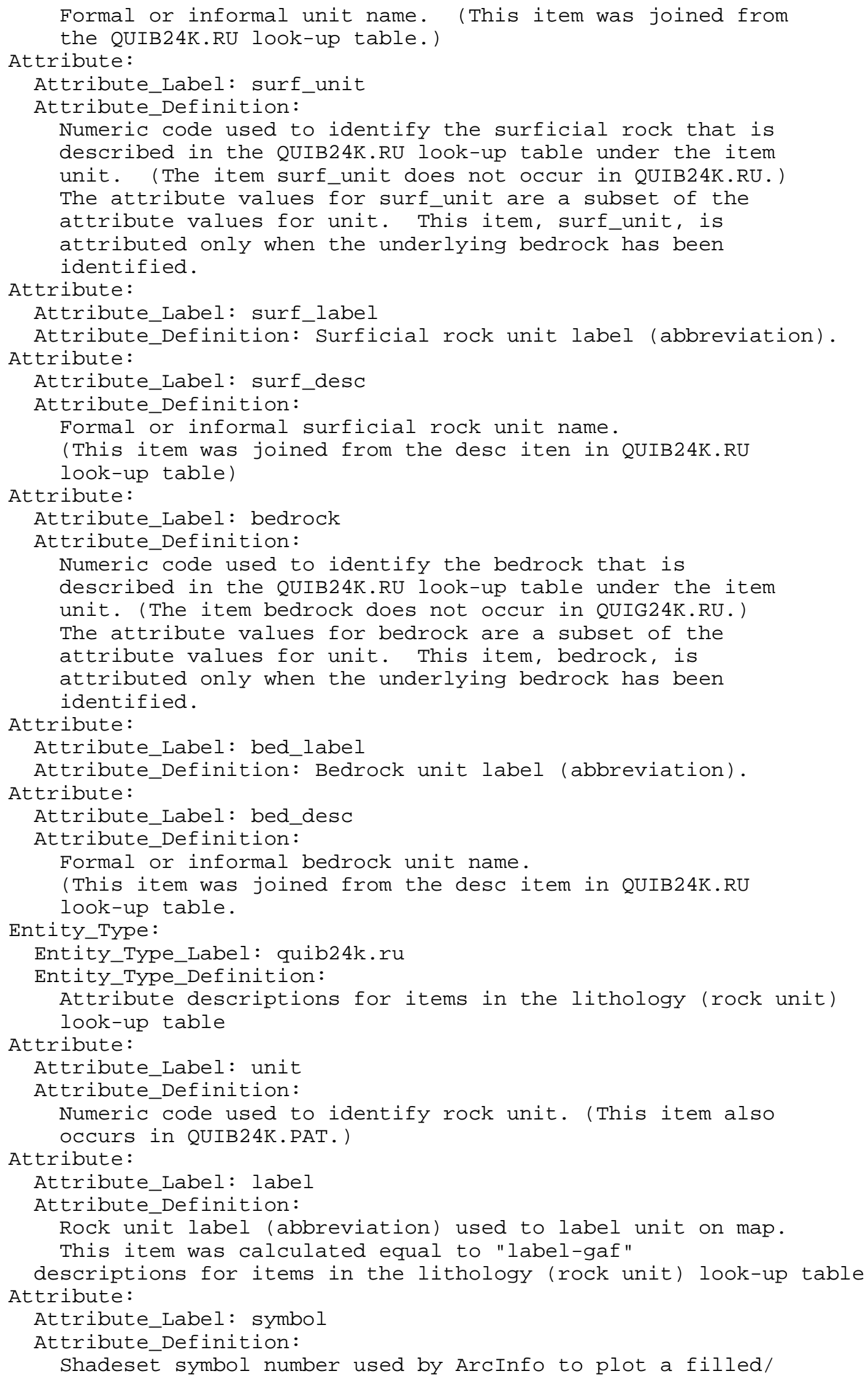


Appendix B

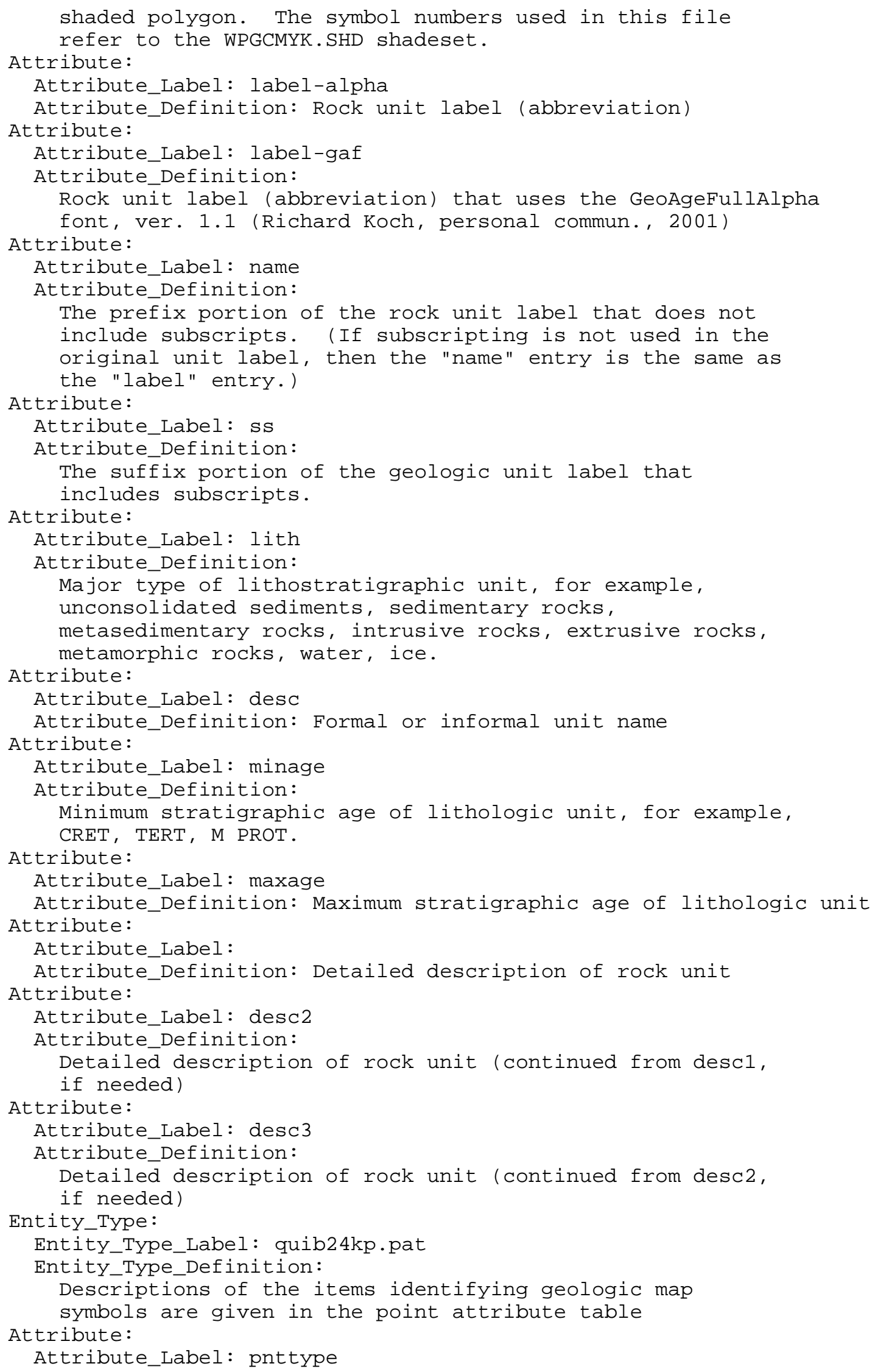




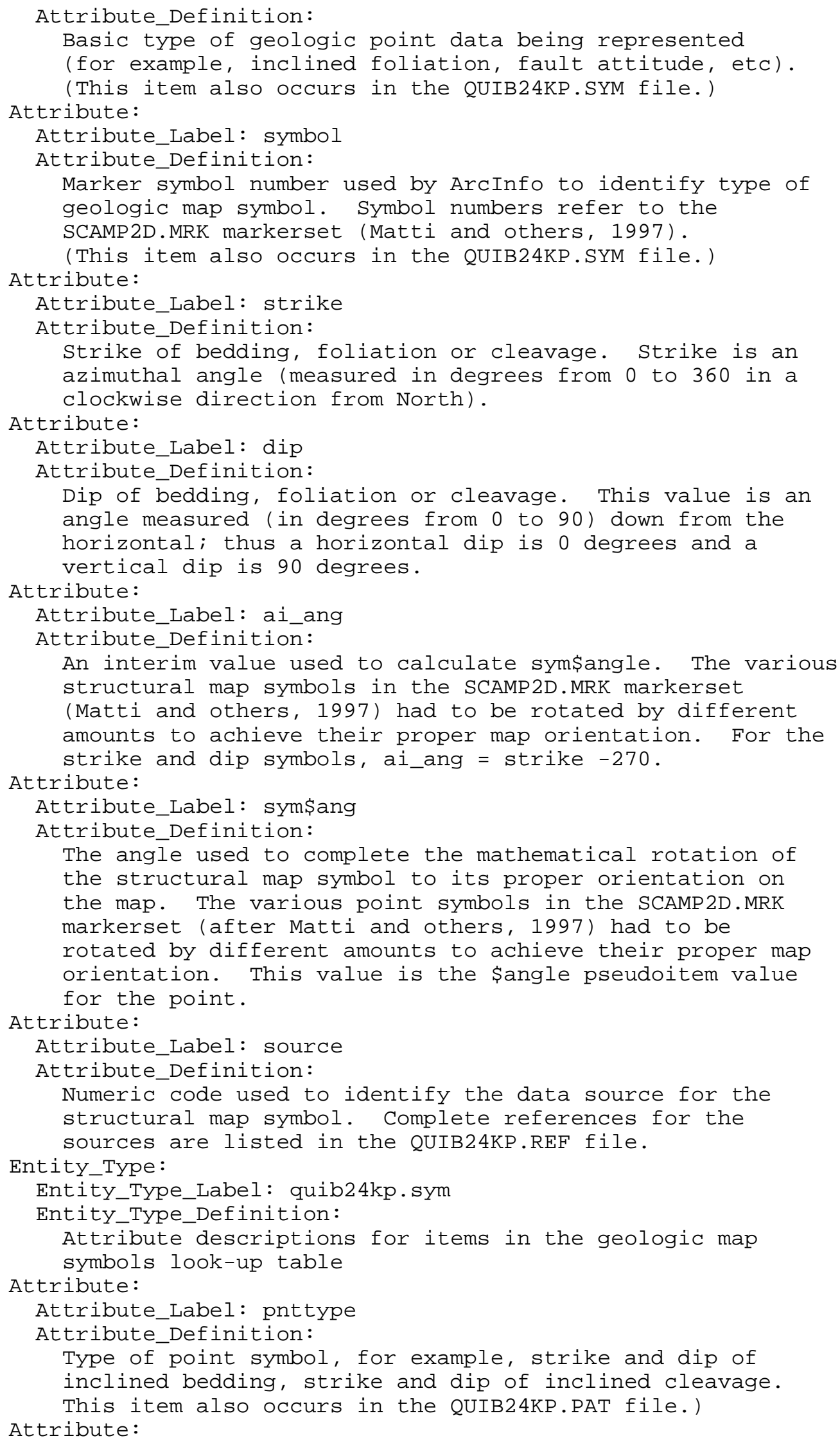


Appendix B

Attribute_Label: symbol

Attribute_Definition:

Marker symbol number used by ArcInfo to identify type of

structural map symbol. Symbol numbers refer to the

SCAMP2D.MRK markerset (Matti and others, 1997).

descriptions for items in the geologic map symbols look-up table

Attribute:

Attribute_Label: desc

Attribute_Definition:

Written description or explanation of map symbol.

Entity_Type:

Entity_Type_Label: quib24k.ref and quib24kp.ref

Entity_Type_Definition:

Descriptive source or reference information for the

quib24k and quib $24 \mathrm{kp}$ ArcInfo datasets

Attribute:

Attribute_Label: source

Attribute_Definition:

Numeric code used to identify the data source. (This item also occurs in the QUIB24K.AAT, QUIB24K.PAT, and QUIB24KP.PAT files.)

Attribute:

Attribute_Label: scale

Attribute_Definition:

Scale of source map. (This value is the denominator of

the proportional fraction that identifies the scale of

the map that was digitized or scanned to produce the digital map.)

Attribute:

Attribute_Label: authors

Attribute_Definition:

Author(s) or compiler(s) of source map entered as last

name, first name or initial, and middle initial.

Attribute:

Attribute_Label: year

Attribute_Definition: Source (map) publication date

Attribute:

Attribute_Label: reference

Attribute_Definition:

Remainder of reference in USGS reference format.

Overview_Description:

Entity_and_Attribute_overview:

The "Spatial Digital Database for the Geology of the San Pedro

River Basin in Cochise, Gila, Graham, Pima, and Pinal Counties, Arizona" report (quib24k.pdf) contains a detailed description of each attribute code and a reference to the associated map symbols in the map source materials. The database includes a geologic linework arc attribute table, quib24k.aat, that relates to the quib24k.co3 (contact look-up table), quib24k.st2 (structure look-up table), quib24k.lgu (linear geologic units look-up table), and quib24k.ref (source reference look-up table) files and a rock unit polygon attribute table, quib24k.pat, that relates to the quib24k.ru (rock unit look-up table) and quib24k.ref (source reference look-up table) files. Associated with this database is a geologic marker point attribute table, quib $24 \mathrm{kp}$.pat that relates to quib24kp.sym (symbol description look-up table) and quib24kp.ref (source reference look-up table).

Entity_and_Attribute_Detail_Citation: 
See the of02-393.pdf file (available at http://geopubs.wr.usgs. gov/open-file/of02-393) for detailed description of items in this database.

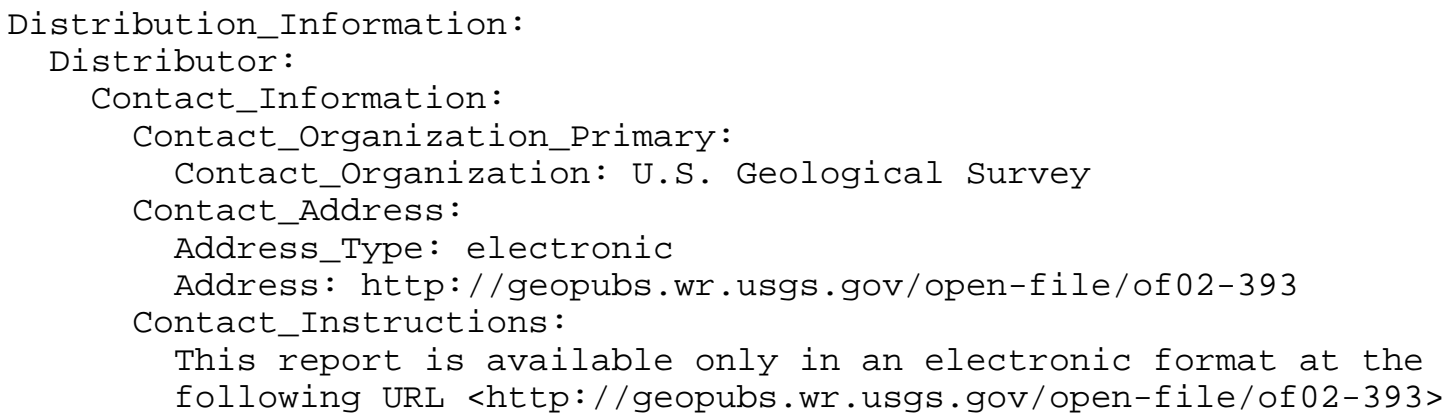

Distribution_Liability:

The U.S. Geological Survey (USGS) provides these geographic data "as is." The USGS makes no guarantee or warranty concerning the accuracy of information contained in the geographic data. The USGS further makes no warranties, either expressed or implied, as to any other matter whatsoever, including, without limitation, the condition of the product or its fitness for any particular purpose. The burden for determining fitness for use lies entirely with the user. Although these data have been processed successfully on computers at the USGS, no warranty, expressed or implied, is made by the USGS regarding the use of these data on any other system, nor does the fact of distribution constitute or imply any such warranty.

In no event shall the USGS have any liability whatsoever for payment of any consequential, incidental, indirect, special, or tort damages of any kind, including, but not limited to, any loss of profits arising out of use of or reliance on the geographic data or arising out of the delivery, installation, operation, or support by USGS.

The digital geologic map GIS of the Quiburis Formation and adjacent units is not meant to be used or displayed at any scale larger than 1:24,000 (for example, 1:12,000 or $1: 2,000)$.

Standard_order_Process :

Digital_Form:

Digital_Transfer_Information:

Format_Name: ARCE; TAR

Format_Information_Content:

This spatial digital database includes a geologic linework arc attribute table, quib24k.aat, that relates to the quib24k.co3, quib24k.st3, quib24k.lgu, and quib24k.ref files and a rock unit polygon attribute table, quib24k.pat, that relates to the quib24k.ru and quib24k.ref files. There is also an associated point table, quib $24 \mathrm{kp}$.pat, that relates to quib $24 \mathrm{kp}$.sym and quib24k.ref. Other files associated with labeling and symbols are also included. Quib24k.pdf contains a complete list of files. A set of the same coverages in geographic format (quib24kg) is also part of the package.

File_Decompression_Technique:

Files need to be extracted from the TAR archive and .e00 files 
Appendix B

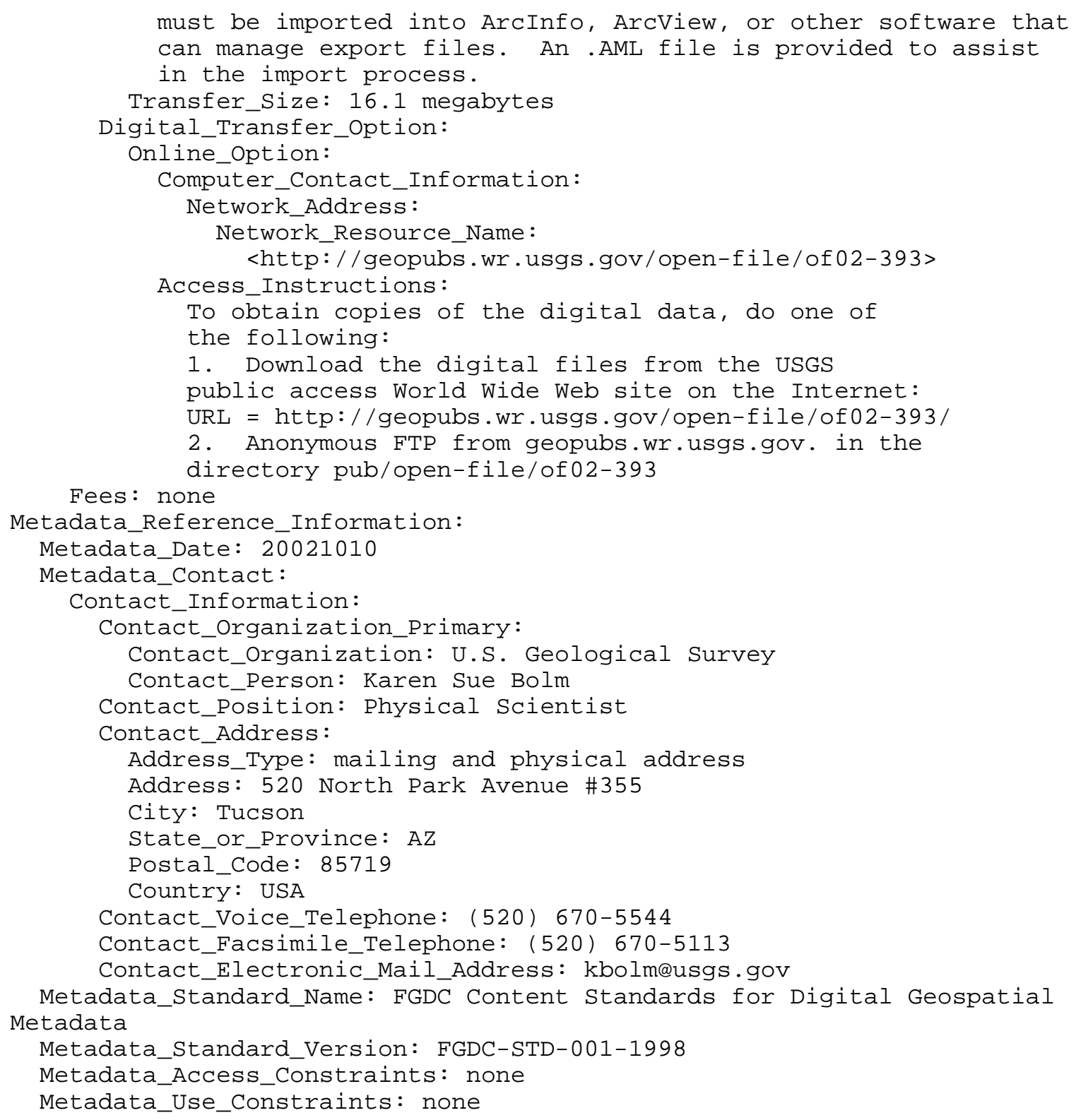

